\title{
A judicialização da política na transição democrática no Brasil (1979-1988) ${ }^{1}$
}

\section{Judicialization of politics in democratic transition in Brazil (1979-1988)}

\author{
Fabiana Luci de Oliveira ${ }^{2}$ \\ Universidade Federal de São Carlos (São Carlos, SP, Brasil) \\ ORCID: https://orcid.org/0000-0003-2324-0106 \\ E-mail: fabianaluci@ufscar.br
}

\section{Resuimo}

O artigo busca descrever os padrões de judicialização da política observados no período de transição democrática no Brasil, por meio da identificação das escolhas de políticas judicializadas pelo Procurador-Geral da República, dos interesses por ele atendidos, e das decisões proferidas pelo Supremo Tribunal Federal nesses casos. A metodologia consiste na análise de conteúdo sistemática das petições iniciais e dos acórdãos das 674 Representações de Inconstitucionalidade que ingressaram no Tribunal entre 15/3/1979 e 4/10/1988, verificando quais grupos de interesse conseguiram levar suas demandas ao STF e quais as taxas de sucesso alcançadas. Recorre-se, também, à cobertura midiática para identificar tentativas barradas de judicialização da política. Os resultados apontam para dois padrões de judicialização da política, com altas taxas de sucesso, atendendo aos interesses do Executivo e da burocracia estatal, com destaque para os magistrados. A estratégia de barrar a judicialização da política passou do arquivamento dos pedidos para a emissão de parecer em defesa da constitucionalidade das normas contestadas.

\section{Palaviras-chave}

Judicialização da Política; Revisão Judicial; Transição Democrática; Procurador-Geral da República; Supremo Tribunal Federal.

\section{Sumário}

1. Introdução. 2. As políticas judicializadas pelo PGR (1979-1988). 3. Tentativas de judicialização da política barradas pelo PGR (1979-1988). 4. Conclusão.

\footnotetext{
${ }^{1}$ OLIVEIRA, Fabiana Luci de. A judicialização da política na transição democrática no Brasil (1979-1988). Suprema: revista de estudos constitucionais, Brasília, v. 1, n. 1, p. 214-240, jan./jun. 2021.
}

${ }^{2}$ Professora Associada do Departamento de Sociologia (UFSCar). Doutora em Ciências Sociais, com pós-doutorado em Ciência Política. Bolsista produtividade do CNPq. Currículo Lattes: https://lattes.cnpq.br/9487149052862292. 


\section{Abstract}

The paper aims at describing the observed patterns of judicialization of politics during transition to democracy in Brazil, through the identification of policy choices judicialized by the Attorney General and the interest groups he attended, as well as the Federal Supreme Court decisions in those cases. The methodology used is the systematic content analysis of the petitions and decisions of the 674 judicial review cases heard by the court between 3/15/1979 and 10/4/1988, seeking to identify which groups of interest managed to take their demands to the court, and their success rates. Media coverage was used to trace attempts to prevent the judicialization of politics. The results point to two patterns of judicialization of politics, with high success rates, meeting the interests of the executive and of the state bureaucracy, especially the interests of judges. The strategy to stop the judicialization of politics went from archiving requests to issuing an opinion in defense of the constitutionality of the contested rules.

\section{Keywords}

Judicialization of Politics; Judicial Review; Democratic Transition; Attorney General; Federal Supreme Court.

\section{Contents}

1. Introduction. 2. Policies judicialized by the PGR (1979-1988). 3. Attempts to judicialize politics barred by the PGR (1979-1988). 4. Conclusion.

\section{Introdução}

Este artigo descreve os padrões de judicialização da política observados no período de transição democrática no Brasil, a partir da identificação das escolhas de políticas judicializadas pelo Procurador-Geral da República (PGR) e dos interesses por ele atendidos, assim como das decisões proferidas pelo Supremo Tribunal Federal (STF) nesses casos. Para isso, são analisadas as petições iniciais e os acórdãos das 674 Representações de Inconstitucionalidade (RP) que ingressaram no Tribunal entre 15/3/1979 e 4/10/1988, buscando responder duas perguntas descritivas: quais interesses foram atendidos pelo PGR e tiveram suas demandas levadas ao STF; e qual a taxa de sucesso das demandas apresentadas 
em RPs. Além disso, recorre-se à cobertura midiática da atuação do PGR no período para identificar tentativas barradas de judicialização da política ${ }^{3}$.

Judicialização da política é o conceito mais mobilizado na literatura especializada para tratar do protagonismo político do Poder Judiciário (VIANNA; BURGOS; SALLES, 2007). É um termo bastante amplo e abarca múltiplas dimensões, o que levou, inclusive, ao questionamento da sua utilidade analítica (KOERNER, 2012; MACIEL; KOERNER, 2002; MACIEL; KOERNER, 2014). A dimensão central do conceito sobre a qual o presente artigo se debruça é a do impacto das decisões judiciais na produção legislativa, pela via do controle abstrato de constitucionalidade.

Nos termos de Tate e Vallinder (1995, p. 13), a judicialização da política significa "a expansão da área de atuação das cortes judiciais ou dos juízes às expensas dos políticos e/ou administradores, isto é, a transferência de direitos de decisão da legislatura, do gabinete ou da administração pública às cortes judiciais”. Além do aumento na incidência de decisões judiciais sobre processos e conflitos políticos, o processo de judicialização que interessa descrever aqui abarca o uso dos tribunais como arena de mobilização da sociedade civil organizada em torno de demandas e interesses sociais e econômicos, no sentido proposto por Domingo (2004, p. 110).

O entendimento predominante nos estudos sobre a judicialização da política no Brasil segue a proposta de Tate e Vallinder (1995), que identificam, entre as condições políticas que facilitariam a ocorrência desse fenômeno, a existência de um regime democrático e constitucional. Apontaria, ainda, não ser possível haver judicialização da política em países que não tenham adotado as normas e as instituições das democracias liberais e aceitado o princípio da independência do Judiciário. Em decorrência disso, esses estudos privilegiaram o cenário pós-Constituição de $1988^{4}$, mas é preciso considerar que o Supremo tem a prerrogativa de examinar a compatibilidade entre leis e atos normativos dos demais Poderes com a Constituição desde o ano de 1965, quando a EC n. 16 estabeleceu o controle abstrato, atribuindo competência ao STF para apreciar "a representação contra inconstitucionalidade de lei ou ato de natureza normativa federal ou estadual, encaminhada pelo Procurador-Geral da República” (CF/1946, art. 101, $k$ apud MENDES, 1990, p. 241).

\footnotetext{
${ }^{3}$ Os dados apresentados neste artigo integram pesquisa que contou com financiamento da FAPESP (2018/00395-9). A autora agradece a colaboração da Coordenadoria de Memória e Gestão Documental do STF, pela prestimosa colaboração na obtenção dos arquivos não localizados no site do Tribunal.
}

${ }^{4}$ Cf. Avritzer e Marona (2014); Carvalho (2004); Oliveira, Falavinha e Braghin (2015); Ribeiro e Arguelhes (2019); Taylor (2008). 
O fato de o Procurador-Geral da República ter, então, a exclusividade no acionamento do STF para o exercício desse controle, teria, na opinião de muitos autores, esvaziado o poder político do Supremo, uma vez que o Tribunal só poderia apreciar a inconstitucionalidade de uma norma caso esse ator (de nomeação e confiança do Presidente da República, demissível ad nutum) submetesse a questão à Corte. Segundo Vieira (1994), "Surgiu, dessa maneira um método de controle concentrado não apenas no sentido técnico-jurídico, mas principalmente político" (VIEIRA, 1994, p. 123). Essa limitação, na visão do autor, só seria superada com a expansão da comunidade de intérpretes legitimados a acionarem diretamente o STF no controle de constitucionalidade das leis. Na perspectiva de Taylor (2008), foram o conteúdo expansivo da Constituição de 1988 e a ampliação dos atores políticos legitimados a ingressar com ações de revisão judicial (veto players) os fatores que mais contribuíram para assegurar a judicialização da política no País, posicionando o Supremo como alternativa aos policymakers tradicionais.

Poucos trabalhos investigaram a judicialização da política ainda durante o regime militar no Brasil. Kapiszewski (2010) é uma das primeiras pesquisadoras a afirmar a ocorrência da judicialização da política durante a transição democrática. A autora atenta que, apesar de o STF ter poderes de revisão abstrata desde 1965, esse fato isolado não seria suficiente para afirmar a ocorrência da judicialização da política, pois tal fenômeno implica não só deter, mas usar efetivamente o poder de revisão judicial para o desempenho de um papel mais ativo na política.

Just because courts are given particular powers (for instance, the ability to carry out judicial review or grab cases from lower courts), or are positioned in a particular way in the institutional super-structure, does not mean that they will use those powers or take advantage of that positioning to play a more active role in politics. And their powers and positioning alone may not account for how they will play any political role they adopt. Furthermore, much of the literature has focused on formal institutions. While these set crucial ground rules and boundaries, particularly (although certainly not only) in institutionally insecure developing democracies such as many in Latin America, consideration of how informal judicial institutions affect the process of judicialization is also important. (...) particular judicial practices, as well as judges 'views of their role, of other judges and courts, and of the relationship they ought to maintain with society, might matter for judicialization. (KAPISZEWSKI, 2010, p. 52) ${ }^{5}$

\footnotetext{
${ }^{5}$ Em tradução livre, "Só porque os tribunais recebem poderes específicos (por exemplo, a capacidade de realizar revisão judicial ou avocar casos de tribunais inferiores), ou estão posicionados de uma forma particular na superestrutura institucional, não significa que eles usarão esses poderes ou aproveitarão esse posicionamento para ter um papel mais ativo na política. E seus poderes e posicionamento por si só podem não explicar como eles desempenharão qualquer papel político que adotem. Além disso, grande parte da literatura enfoca as instituições formais. Embora estabeleçam regras básicas e limites cruciais, particularmente (embora
} 
Alinhada a Arantes (2002, p. 93), que observou crescimento significativo de ações de controle de constitucionalidade propostas pelo PGR no STF entre 1985 e 1988, Kapiszewski (2010) localiza a ocorrência do fenômeno da judicialização da política a partir de 1985, quando o Supremo passou a ser mais ativamente acionado para decidir uma ampla gama de casos politicamente importantes, tendo esse fenômeno se acirrado a partir da promulgação da Constituição de 1988.

Câmara (2017) é outra a afirmar a possibilidade de judicialização da política pré-Constituição de 1988, desafiando tese corrente de que o constitucionalismo pré-1988 não teria eficácia, sendo apenas uma "fachada” para práticas autoritárias. A autora analisou 65 RPs decididas pelo STF entre os anos de 1965 e 1968 e afirmou que, embora esse instrumento tenha tido aplicabilidade bastante reduzida até 1967 , tratando da disputa em torno da criação de municípios e outras questões envolvendo a relação entre estados e municípios, o Supremo foi capaz de atuar politicamente mesmo em uma situação de excepcionalidade. Isso porque, no processo decisório do Tribunal, foram identificadas divergências nos votos entre os ministros, relativas às concepções da relação entre direito e política (CÂMARA, 2017, p. 241-242).

Já Arguelhes e Süssekind (2018) encontraram evidências de judicialização da política na atuação do STF no episódio da emenda constitucional Dante de Oliveira. Segundo os autores, ao ser provocado a decidir sobre um conflito político sobre as regras do jogo do processo de transição democrática (interpretando o quórum constitucional para a aprovação de emendas), o Tribunal teria reformulado o sentido de normas constitucionais, criando novas regras - um dos indicadores mais acionados para afirmar a ocorrência de judicialização da política e mesmo de ativismo judicial ${ }^{6}$.

Na decisão, o STF se afastou do teor literal da constituição vigente e de sua própria jurisprudência anterior. Provocado por atores políticos a resolver um conflito fundamental sobre as próprias regras do jogo do processo de transição para democracia, o STF resolveu a questão clarificando/ reformulando o sentido de normas constitucionais. Ao fazê-lo, criou novas regras gerais vinculantes para futuros conflitos políticos, reforçando sua

\footnotetext{
certamente não apenas) em democracias em desenvolvimento institucionalmente inseguras, como muitas na América Latina, a consideração de como as instituições judiciais informais afetam o processo de judicialização também é importante. (...) práticas judiciais particulares, bem como as visões dos juízes sobre o seu papel, de outros juízes e tribunais, e da relação que devem manter com a sociedade, podem ser importantes para a judicialização".

${ }^{6}$ Os termos "judicialização da política” e "ativismo judicial” costumam ser empregados para tratar da expansão do poder político do Judiciário. Entretanto, apesar da proximidade, os conceitos não são intercambiáveis. O ministro Luís Roberto Barroso diferencia os conceitos a partir das dimensões factual e atitudinal. Enquanto a judicialização da política é factual, significando que questões de ampla repercussão política ou social passaram a ser decididas pelo Judiciário, e não pelas instâncias representativas tradicionais, o ativismo judicial é uma atitude proativa do Judiciário, que passa a interpretar princípios e regras constitucionais de forma não prevista expressamente pelo legislador (BARROSO, 2017, p. 12).
} 
própria autoridade como corte constitucional, mesmo em um ambiente não democrático, lançando as bases para o mesmo tipo de autoridade que viria a utilizar já após a transição democrática. (ARGUELHES; SÜSSEKIND, 2018, p. 2)

Oliveira (2019, p. 82) figura entre os autores que afirmam a ocorrência da judicialização da política durante a transição democrática, constatando, a partir da análise da agenda decisória do STF nas RPs julgadas pelo Tribunal entre 1978 e 1988, que o controle de constitucionalidade foi utilizado majoritariamente para mediar conflitos ligados ao arranjo federativo.

Entre os papéis desempenhados por tribunais em regimes autoritários, conforme descrito por Ginsburg e Moustafa (2008), o STF esteve mais próximo de colaborar para manter a disciplina burocrática dentro das instituições do Estado, e ao mesmo tempo, servir como espaço privilegiado para a deliberação de interesses econômicos e corporativos, via gestão de conflitos de interesse das associações e sindicatos patronais e das associações das carreiras públicas, com destaque para as carreiras do próprio sistema de justiça. O mapeamento da agenda decisória do Supremo em controle abstrato de constitucionalidade no período de transição democrática mostrou a presença de elementos relacionados à judicialização de políticas públicas, confirmando sua ocorrência antes mesmo da Constituição de 1988, especialmente no sentido posto por Domingo (2004), de interesses organizados que levam ao tribunal demandas corporativas e econômicas, e, ainda que menos frequentes, sociais. (OLIVEIRA, 2019, p. 93)

Tomando como ponto de partida as conclusões alcançadas por esse conjunto de trabalhos, que afirmam a aplicabilidade do conceito de judicialização da política em cenários não democráticos, busca-se aqui descrever os padrões de judicialização da política observados no período de transição para a democracia. A principal inovação e contribuição do artigo é identificar padrões de judicialização da política no período, a partir do perfil de atuação dos três profissionais que ocuparam a posição de PGR entre março de 1979 e outubro de 1988, uma vez que esse ator controlava o ingresso das ações de Representação de Inconstitucionalidade no STF, atuando como uma espécie de gatekeeper (guardião dos portões) do Tribunal em matéria de revisão judicial.

A escolha do recorte temporal segue avaliação corrente na literatura sobre processo decisório judicial, a qual aponta que, entre a edição do AI-5, em 1968, até a sua revogação em 1978, o STF teve pouca margem de atuação na revisão judicial. Nas palavras de Koerner, sob a vigência do AI-5 o Tribunal “(...) foi desvestido de seu papel de garantir os direitos políticos da oposição e da contestação política” (KOERNER, 
2012, p. 34). A análise inicia-se em 1979, quando Firmino Ferreira Paz assumiu o posto, e se encerra no dia anterior à promulgação da nova Constituição.

Na próxima seção, são descritas as políticas judicializadas pelo PGR, identificando os assuntos e as partes interessadas, assim como as taxas de sucesso obtidas nessas ações, de acordo com os grupos de interesse organizados. São descritos, também, os níveis de dissenso no Tribunal ao longo do período. Na sequência, é apresentada uma amostra das tentativas barradas de judicialização da política, a partir da cobertura que os jornais Folha de S. Paulo e O Estado de S. Paulo fizeram da atuação da PGR no período. $\mathrm{O}$ artigo encerra-se com a apresentação das conclusões da pesquisa.

\section{As políticas judicializadas pelo PGR (1979-1988)}

Entre 15 de março de 1979 e 11 de junho de 1981, a função de procurador-geral da República foi desempenhada por Firmino Ferreira Paz, que iniciou sua carreira no Ministério Público do Estado do Piauí, atuando como procurador da República até se aposentar, quando passou, então, a advogar ${ }^{7}$. Firmino Paz ocupava o cargo de juiz do Tribunal Superior Eleitoral (TSE), na classe dos advogados, quando foi nomeado pelo Presidente João Batista Figueiredo para a PGR. Nos dois anos e sete meses em que permaneceu à frente da instituição, Firmino Paz ingressou com 91 RPs: 86\% questionando normas estaduais; 9\%, federais; e 6\%, normas provenientes do Judiciário.

Inocêncio Mártires Coelho foi seu sucessor. Ingressou no Ministério Público como procurador da República, em concurso em 1974. Ocupava o cargo de consultor jurídico do ministro-chefe da Casa Civil, Golberi do Couto e Silva, quando foi nomeado pelo Presidente João Batista Figueiredo para o cargo de PGR, permanecendo no posto até 15 de março de 1985. Nos três anos e quatro meses em que atuou como PGR, protocolou 140 RPs: $89 \%$ delas contestavam diplomas estaduais; 2\%, federais; e 9\%, judiciais.

José Paulo Sepúlveda Pertence assumiu como PGR na sequência, permanecendo no posto até 17 de maio de 1989. Aqui considera-se apenas sua atuação até a promulgação da Constituição de 1988. Sepúlveda Pertence ingressou no MPF em 1965, mas foi cassado em 1969, passando a advogar. Com base na lei da

\footnotetext{
${ }^{7}$ As informações biográficas dos PGR foram obtidas no site do MPF (BRASIL, [2021]), e no Dicionário Histórico-Biográfico Brasileiro, no site do CPDOC (FUNDAÇÃO GETÚLIO VARGAS, [2021]).
} 
anistia política, foi reintegrado à carreira em 1979, sendo nomeado por Sarney, em 1985, para ocupar a PGR. Em 3 anos e 8 meses, Sepúlveda Pertence protocolou 443 RPs no Supremo: $86 \%$ contra normas estaduais; $11 \%$ contra normas federais; e $3 \%$ contra normas judiciais.

A tabela 1 apresenta o perfil de judicialização de acordo com a área da norma questionada na ação. A criação de municípios foi a área de maior judicialização, correspondendo a pouco menos de $1 / 3$ do total de ações (29\%). A expressividade numérica desse tema no STF pode ser entendida primeiro a partir de dados do Instituto Brasileiro de Geografia e Estatística (IBGE, 2010), que mostram que o Brasil passou de 2.766 municípios em 1960, para 3.952 em 1970. Em 1980 chegou a 3.974 municípios e, em 1991, a 4.491. A própria Presidência do IBGE foi responsável por 63\% dos pedidos de RPs contra a criação de municípios. Essas solicitações foram concentradas no ano de 1988 - 73\% das RPs que questionaram a criação de municípios ingressaram no Tribunal em 1988. As duas unidades federativas com maior volume de ações nesse tema foram Goiás (47\%) e Rio Grande do Sul (27\%).

\section{Tabela 1 - Área temática das políticas judicializadas no período, de acordo com o PGR}

\begin{tabular}{|c|c|c|c|c|}
\hline \multirow[b]{2}{*}{ Área da norma } & \multirow{2}{*}{$\begin{array}{c}\text { Total } \\
(1979- \\
1988)\end{array}$} & \multicolumn{3}{|c|}{ PGR } \\
\hline & & $\begin{array}{c}\text { Firmino } \\
\text { Paz }\end{array}$ & $\begin{array}{c}\text { Mártires } \\
\text { Coelho }\end{array}$ & $\begin{array}{l}\text { Sepúlveda } \\
\text { Pertence }\end{array}$ \\
\hline Criação de município & $29 \%$ & $14 \%$ & $9 \%$ & $38 \%$ \\
\hline Carreiras públicas & $18 \%$ & $22 \%$ & $17 \%$ & $17 \%$ \\
\hline Organização das instituições da justiça & $14 \%$ & $22 \%$ & $17 \%$ & $11 \%$ \\
\hline Organização das instituições do Estado & $12 \%$ & $17 \%$ & $19 \%$ & $9 \%$ \\
\hline Política fiscal e tributária & $8 \%$ & $2 \%$ & $13 \%$ & $7 \%$ \\
\hline Carreiras públicas da justiça & $7 \%$ & $8 \%$ & $9 \%$ & $6 \%$ \\
\hline Política econômica & $6 \%$ & $4 \%$ & $9 \%$ & $6 \%$ \\
\hline Direitos fundamentais & $6 \%$ & $10 \%$ & $3 \%$ & $5 \%$ \\
\hline Partidos e eleições & $2 \%$ & $1 \%$ & $4 \%$ & $1 \%$ \\
\hline $\mathbf{N}$ & 674 & 91 & 140 & 443 \\
\hline
\end{tabular}

Fonte: Elaborada pela autora. 
A segunda área mais judicializada foi o funcionalismo público, segmentado em duas categorias: carreiras públicas da justiça (reunindo magistratura, ministério público, delegados e advocacia pública) e carreiras públicas (englobando todos os demais servidores). A primeira representa $7 \%$ do total de ações; e a segunda, $18 \%$. Tanto governadores quanto as associações dessas carreiras ou servidores individualmente representaram ao PGR para questionar a constitucionalidade de normas referentes ao pagamento de vencimentos e benefícios, férias e aposentadoria.

Oliveira mostrou que o funcionalismo público dominou a pauta do STF entre 1988 e 2014 - 40\% das ADINs decididas no período -, concluindo que o STF dedicou "... boa parte do seu tempo atuando como um setor de recursos humanos, ao arbitrar interesses de agentes públicos em conflito e colocar-se na posição de decidir pela ampliação ou redução de benefícios aos servidores" (OLIVEIRA, 2016, p. 113). Os dados da tabela 1 permitem afirmar que a via judicial já era utilizada de forma expressiva para disputar a constitucionalidade da expansão ou redução de benefícios e vantagens das carreiras públicas antes mesmo da Constituição de 1988, ocupando 1/4 da agenda decisória do Tribunal no período de transição democrática.

As regras de organização das instituições de justiça aparecem como o terceiro assunto mais judicializado (14\%). Tratam da realização de concurso público, da criação de cargos e do delineamento institucional. O tema da organização das demais instituições do Estado vem a seguir, com ações sobre contratações no âmbito da administração pública, e organização institucional, criação de cargos e concurso para outras carreiras do Estado que não as da justiça. Esse tema teve maior destaque nas gestões de Mártires Coelho e Firmino Paz. Políticas nas áreas fiscal e tributária totalizaram $8 \%$ das ações protocoladas no período. Política econômica e agenda de direitos fundamentais, assim como o funcionamento de partidos e eleições, foram as políticas menos judicializadas $-6 \%$ e $2 \%$ dos pedidos, respectivamente.

Como o PGR detinha a exclusividade de ingresso da ação de inconstitucionalidade no STF, as partes interessadas peticionavam junto a ele sua propositura; ele acolhia o pedido, encaminhando a RP ao Supremo, ou recusava, arquivando-o. Esse poder de filtragem de demandas, que transformou o PGR em gatekeeper do STF, foi contestado no próprio Tribunal. O MDB (Movimento Democrático Brasileiro) ingressou com a Reclamação 849, contra decisão do PGR de arquivamento da solicitação feita pelo partido para arguição de inconstitucionalidade do Decreto-lei 1.077, de 26 de janeiro de 1970, que instituía a censura prévia de livros, jornais e periódicos. Xavier de Albuquerque, então PGR, recusou-se a submeter a questão ao Supremo, por entender que não estava constitucionalmente obrigado a fazê-lo. O Supremo rejeitou a reclamação, contra o voto do ministro Adaucto Cardoso, reconhecendo, portanto, a discricionariedade absoluta do Procurador-Geral da República em ingressar ou não com a representação de inconstitucionalidade junto ao STF (MENDES, 1997, p. 143). 
No exercício dessa arbitrariedade, o grupo de interesse organizado com a maior quantidade de ações acolhidas pelo PGR foi a burocracia estatal, que figura como parte interessada em quase um terço das RPs protocoladas no período (28\%). Esse segmento foi dividido em três categorias (conforme tabela 2): magistratura (4\%), burocracia jurídica (ministério público, advocacia pública e delegados, com 6\%) e burocracia (demais servidores, com 22\%). Cada categoria questionava normas relativas às suas carreiras. Os pedidos de magistrados tiveram maior incidência relativa na gestão de Firmino Paz. Já as solicitações das demais carreiras públicas da justiça tiveram maior representatividade na gestão de Inocêncio Mártires Coelho; e os demais servidores, na gestão de Sepúlveda Pertence - neste último caso, majoritariamente tratando da criação de municípios por parte da Presidência do IBGE, e não de assuntos relativos à carreira.

Tabela 2 - Parte interessada na ação no período, de acordo com o PGR

\begin{tabular}{l|c|c|c|c}
\hline \multirow{2}{*}{ Interessado na ação } & Total (1979- & \multicolumn{3}{|c}{ PGR } \\
\cline { 4 - 5 } & $\mathbf{1 9 8 8}$ & $\begin{array}{c}\text { Firmino } \\
\text { Paz }\end{array}$ & $\begin{array}{c}\text { Mártires } \\
\text { Coelho }\end{array}$ & $\begin{array}{c}\text { Sepúlveda } \\
\text { Pertence }\end{array}$ \\
\hline Executivo estadual & $\mathbf{2 4 \%}$ & $40 \%$ & $21 \%$ & $21 \%$ \\
\hline Burocracia (servidores) & $\mathbf{2 2 \%}$ & $3 \%$ & $6 \%$ & $31 \%$ \\
\hline Advogado/OAB & $\mathbf{1 3 \%}$ & $13 \%$ & $9 \%$ & $14 \%$ \\
\hline Sindicatos patronais/ empresas & $\mathbf{1 2 \%}$ & $4 \%$ & $24 \%$ & $9 \%$ \\
\hline Burocracia jurídica & $\mathbf{6 \%}$ & $7 \%$ & $11 \%$ & $5 \%$ \\
\hline Executivo municipal & $\mathbf{5 \%}$ & $4 \%$ & $5 \%$ & $6 \%$ \\
\hline Legislativo estadual & $\mathbf{4 \%}$ & $7 \%$ & $7 \%$ & $3 \%$ \\
\hline Magistratura & $\mathbf{4 \%}$ & $11 \%$ & $4 \%$ & $3 \%$ \\
\hline Associações/sindicatos & $\mathbf{4 \%}$ & $3 \%$ & $5 \%$ & $3 \%$ \\
\hline trabalho) & $\mathbf{3 \%}$ & $3 \%$ & $1 \%$ & $3 \%$ \\
\hline Sociedade & $\mathbf{2 \%}$ & $3 \%$ & $3 \%$ & $2 \%$ \\
\hline Legislativo municipal & $\mathbf{1 \%}$ & $1 \%$ & $4 \%$ & $1 \%$ \\
\hline Executivo federal & $\mathbf{6 7 4}$ & $0 \%$ & $1 \%$ & $1 \%$ \\
\hline Legislativo federal & $\mathbf{9 1}$ & $\mathbf{1 4 0}$ & $\mathbf{4 4 3}$ \\
\hline N & & & & $2 \%$ \\
\hline
\end{tabular}

Fonte: Elaborada pela autora. 
Os governadores vêm na sequência, responsáveis por quase $1 / 4$ das RPs protocoladas. Nessas ações, questionam normas sobre carreira, organização e competência dos Poderes, e outros temas ligados à administração pública, como convênios e contratações.

O grupo dos advogados aparece em terceiro lugar, como parte interessada em 13\% das RPs. A maior parte dessas ações foi proposta pela própria OAB, mas é preciso ponderar que em alguns dos pedidos figuram como parte interessada advogados individualmente, o que eventualmente pode ocultar algum outro grupo de interesse organizado que esse advogado representasse. Setores empresariais figuram como parte interessada em $12 \%$ das RPs, sendo que foram proporcionalmente mais incidentes na gestão Mártires Coelho - quase 1/4 das RPs protocoladas por Coelho atendiam a representações de empresas ou sindicatos patronais.

Associações de trabalhadores e de profissionais liberais juntas somam 4\% das ações; e a categoria sociedade civil (agrupando representações encaminhadas ao PGR por cidadãos, associação de moradores e representante das nações indígenas), 3\%.

O STF respondeu de forma predominantemente favorável às representações, com uma taxa de sucesso total de 56\%. Seguindo Taylor e Da Ros (2008, p. 830), aqui a taxa de sucesso é dada pela proporção das decisões que inviabilizaram parcial ou integralmente a legislação sob escrutínio, considerando tanto as decisões de mérito quanto o efeito das liminares ${ }^{8}$. A taxa geral de sucesso das RPs pode ser considerada alta se comparada à taxa de sucesso das ADINs. No estudo de Taylor e Da Ros (2008), que analisaram ADINs contra normas federais editadas nos governos FHC e no primeiro governo Lula, cobrindo o período de 1995 a 2008, a taxa de sucesso observada foi de $20,1 \%$, considerand o o total de ações impetradas, e 32,6\%, considerando apenas as ações efetivamente julgadas. Oliveira (2016) chegou a resultado semelhante, considerando a totalidade das ADINs decididas no período de 1989 a 2014: 33\% foram declaradas procedentes, no todo ou em parte.

Os grupos de interesses organizados que acionaram o PGR para judicializar sua contrariedade a determinadas políticas alcançaram diferentes taxas de sucesso, assim como o STF foi mais receptivo a determinadas áreas de políticas. O gráfico 1 apresenta as taxas de sucesso das RPs de acordo com as variáveis: origem da norma contestada; parte interessada na representação; ocupante do cargo de PGR; e área da política judicializada9 .

\footnotetext{
${ }^{8}$ Foram contabilizadas como favoráveis ao pleiteante as RPs com dois tipos de decisão: 1 ) com mérito procedente (no todo ou em parte) e 2) com liminar deferida (no todo ou em parte) e julgada prejudicada no mérito por perda de objeto.

${ }^{9}$ As diferenças observadas entre as taxas de sucesso dentro de cada uma dessas variáveis (origem da norma contestada, parte interessada na representação, ocupante do cargo de PGR e área da política judicializada) são estatisticamente significativas, a partir do teste de qui-quadrado $(p$-value $=0.00)$.
} 


\section{Gráfico 1 - Taxa de sucesso no STF, de acordo com a origem da norma contestada, os interesses representados, o PGR e a área da política}

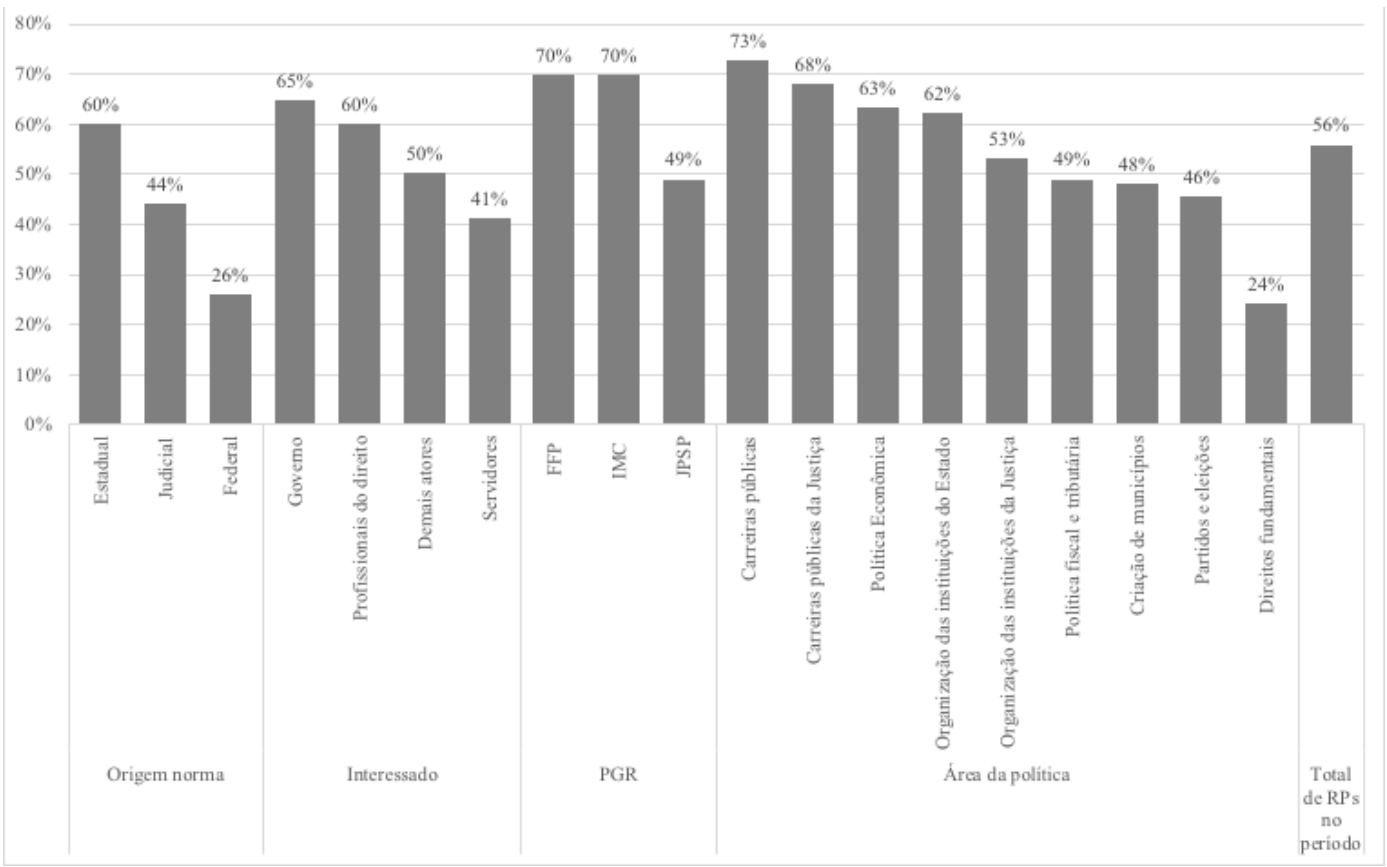

Fonte: Elaborado pela autora.

O STF decidiu favoravelmente à maioria dos pedidos que contestaram normas estaduais (60\%). Foi um pouco menos receptivo às ações que contestaram normas do Judiciário, julgando favoravelmente $44 \%$ dos pedidos, e pouco receptivo às ações que questionaram normas federais (24\% de taxa de sucesso). Atendeu à maioria dos pedidos de Firmino Paz e Mártires Coelho, que tiveram resposta favorável do STF em 70\% dos casos que protocolaram. A menor taxa de sucesso de Sepúlveda Pertence (49\%) pode ser interpretada a partir de dois fatores. Primeiro, em decorrência do alto número de ações que perderam o objeto antes de qualquer decisão do Supremo, uma vez que $60 \%$ do total de 194 RPs propostas por Sepúlveda Pertence ingressaram no STF em 1988, próximo ao advento da nova Constituição. Segundo, por estratégia adotada por Sepúlveda Pertence para evitar arquivar petições de representação de inconstitucionalidade, encaminhando junto com a inicial da RP um parecer pela constitucionalidade da norma sob ataque, quando discordava do pedido (CANÁRIO; GALLI, 2016). 
No que se refere à área da política, a regulação das carreiras públicas foi a que teve proporção maior das normas questionadas inviabilizadas - $68 \%$ das ações questionando normas atinentes às carreiras públicas de justiça e $73 \%$ das ações contestando normas das demais carreiras públicas tiveram decisão favorável. Em contrapartida, o Supremo foi menos receptivo às demandas que buscaram inviabilizar normas na área de direitos fundamentais, respondendo favoravelmente a $26 \%$ do total de pedidos.

Os grupos de interesse organizado que tiveram maior sucesso no Supremo foram o governo (todos os níveis) e os profissionais do direito (incluindo as carreiras públicas de justiça e os advogados). Em contrapartida, o Supremo foi menos receptivo às demandas dos servidores (excluindo os membros das carreiras da justiça). $\mathrm{Na}$ tabela 3 é possível observar as taxas de sucesso, desagregando os diferentes grupos de interesse, de acordo com a origem da norma contestada. O Executivo federal e os magistrados foram os grupos de interesse com maior proporção de demandas atendidas no STF, mesmo quando contestaram normas federais, seguidos de perto pelo Executivo estadual. A burocracia jurídica também observou uma taxa média de sucesso alta, com $60 \%$ das demandas atendidas pelo STF. Já o Legislativo federal teve poucas ações levadas ao STF, não obtendo sucesso em nenhum caso. Os trabalhadores são o segundo grupo de interesse com menor proporção de decisões favoráveis, com taxa de sucesso de $24 \%$. O grupo dos servidores (excluindo a burocracia jurídica) também teve proporcionalmente mais derrotas que vitórias na judicialização de políticas. 


\section{Tabela 3 - Quantidade de ações e taxa de sucesso no STF por interessado, de acordo com a origem da norma}

\begin{tabular}{|c|c|c|c|c|c|c|c|c|}
\hline \multirow[t]{2}{*}{ Interessado na ação } & \multirow{2}{*}{$\begin{array}{l}\text { Total } \\
\text { de RPs }\end{array}$} & \multicolumn{3}{|c|}{ RP por origem da norma } & \multirow{2}{*}{$\begin{array}{l}\text { Total da } \\
\text { taxa de } \\
\text { sucesso }\end{array}$} & \multicolumn{3}{|c|}{$\begin{array}{c}\text { Taxa de sucesso pela } \\
\text { origem da norma }\end{array}$} \\
\hline & & Est. & Fed. & Jud. & & Est. & Fed. & Jud. \\
\hline Executivo estadual & 159 & 153 & 4 & 2 & $73 \%$ & $74 \%$ & $50 \%$ & $50 \%$ \\
\hline $\begin{array}{l}\text { Burocracia } \\
\text { (servidores) }\end{array}$ & 148 & 144 & 4 & - & $41 \%$ & $42 \%$ & $25 \%$ & - \\
\hline Advogados & 85 & 63 & 11 & 11 & $55 \%$ & $64 \%$ & $9 \%$ & $55 \%$ \\
\hline Empresários & 78 & 66 & 10 & 2 & $58 \%$ & $67 \%$ & $10 \%$ & $0 \%$ \\
\hline Burocracia jurídica & 42 & 34 & 4 & 4 & $60 \%$ & $62 \%$ & $50 \%$ & $50 \%$ \\
\hline Executivo municipal & 36 & 34 & 2 & - & $44 \%$ & $47 \%$ & $0 \%$ & - \\
\hline Legislativo estadual & 29 & 25 & 1 & 3 & $55 \%$ & $64 \%$ & $0 \%$ & $0 \%$ \\
\hline Magistratura & 28 & 14 & 5 & 9 & $75 \%$ & $86 \%$ & $80 \%$ & $56 \%$ \\
\hline Trabalhadores & 25 & 15 & 9 & 1 & $24 \%$ & $20 \%$ & $33 \%$ & $0 \%$ \\
\hline Sociedade & 18 & 15 & 3 & - & $56 \%$ & $67 \%$ & $0 \%$ & - \\
\hline $\begin{array}{l}\text { Legislativo } \\
\text { municipal }\end{array}$ & 15 & 13 & 2 & - & $53 \%$ & $62 \%$ & $0 \%$ & - \\
\hline Executivo federal & 8 & 7 & 1 & - & $75 \%$ & $71 \%$ & $100 \%$ & - \\
\hline Legislativo federal & 3 & 1 & 2 & - & $0 \%$ & $0 \%$ & $0 \%$ & - \\
\hline Total & 674 & 584 & 58 & 32 & $56 \%$ & $60 \%$ & $26 \%$ & $44 \%$ \\
\hline
\end{tabular}

Fonte: Elaborada pela autora.

Um último dado que interessa observar para descrever o padrão de judicialização da política no período de transição democrática é o nível de consenso no processo decisório do STF. O Tribunal foi bastante consensual no período como um todo (ver gráfico 2), com apenas $10 \%$ do total de RPs apresentando algum voto dissidente ${ }^{10}$. Embora decisões sobre a inconstitucionalidade das normas federais apresentem

\footnotetext{
${ }^{10}$ Como parâmetro para leitura desses dados, observa-se que o Supremo pós-Constituição de 1988 não se tornou menos consensual, mas, sim, mais monocrático. No período de 1979 a 1988, apenas $1 \%$ das decisões finais em RPs foram dadas pelo relator, monocraticamente. Já no período de 1989 a 2014, de acordo com Oliveira (2016), 48\% das ADINs tiveram decisão final monocrática, e $15 \%$ foram decididas com algum voto dissidente.
} 
proporcionalmente maior divergência, as diferenças observadas não são estaticamente significativas. Já as diferenças observadas entre os períodos, com base em quem era o titular na PGR, são estatisticamente significativas, com o período de Firmino Paz apresentando a maior proporção de divergência na Corte.

Gráfico 2 - Dissenso no STF, de acordo com a origem da norma contestada, considerando o período total e o PGR que propôs a ação

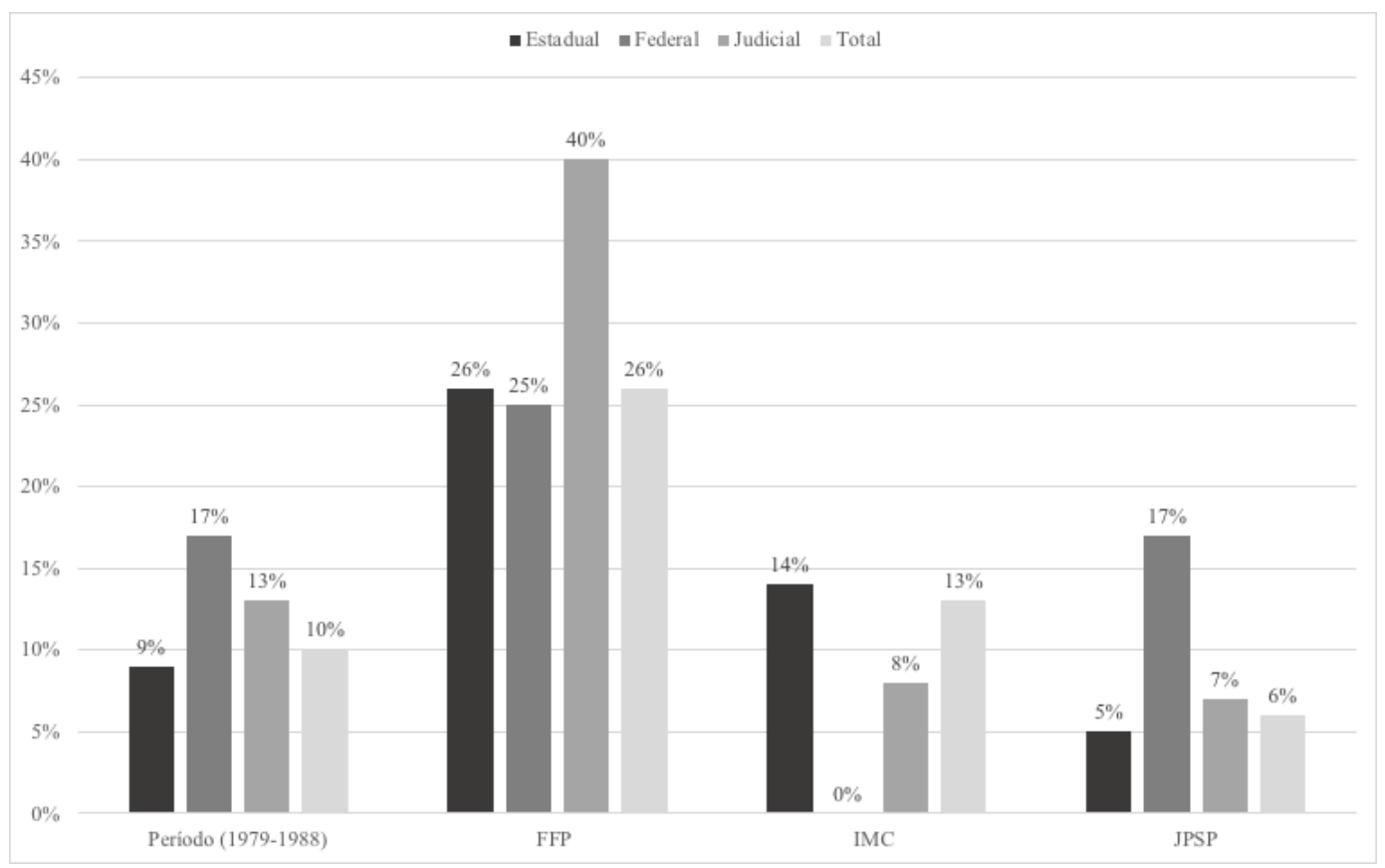

Fonte: Elaborado pela autora.

Isso pode dever-se, em parte, à composição do STF. Os seis ministros que apresentaram as maiores proporções de votos divergentes no período ${ }^{11}$ foram Clovis Ramalhete, Xavier de Albuquerque, Néri da Silveira, Célio Borja, Cunha Peixoto e Leitão de Abreu. Com exceção de Borja, todos estavam no Supremo na gestão de Firmino Paz, e quatro deles (Clovis Ramalhete, Xavier de Albuquerque, Cunha Peixoto e Leitão de Abreu) deixaram o STF nos períodos seguintes.

\footnotetext{
${ }^{11}$ Esses seis ministros foram considerados os mais dissidentes no período, pois ficaram na minoria em pelo menos $1 / 3$ das ações majoritárias em que votaram.
} 


\section{Tentativas de judicialização da política barradas pelo PGR (1979-1988)}

Recorreu-se à cobertura midiática para identificar tentativas barradas de judicialização da política no período de transição democrática. A partir do termo de busca "procurador-geral da República”, foram localizadas 305 notícias que tratavam da atuação do PGR no controle de constitucionalidade, publicadas nos jornais Folha de S. Paulo e O Estado de S. Paulo, entre 15/3/1979 e 4/10/1988 ${ }^{12}$. Dessas notícias, apenas $11 \%$ eram relativas ao arquivamento de pedidos de representação de inconstitucionalidade dirigidos ao PGR.

Houve redução significativa da incidência de notícias sobre arquivamento de RPs entre as gestões de Firmino Paz e Mártires Coelho para a de Sepúlveda Pertence. Na cobertura jornalística da atuação de Firmino Paz em controle de constitucionalidade, $20 \%$ das notícias eram sobre pedidos arquivados pelo PGR; na gestão de Mártires Coelho, os arquivamentos representaram 23\% das notícias; e na de Sepúlveda Pertence, caíram para apenas $1 \%$ das notícias referentes ao papel do PGR no controle de constitucionalidade.

A primeira notícia localizada sobre arquivamento de RP no período tratava de petição encaminhada a Firmino Paz pelo Instituto dos Advogados Brasileiros, do Rio de Janeiro, para arguição de inconstitucionalidade do Decreto-lei 1.782, de 16 de abril de 1980, que instituía o empréstimo compulsório para absorção temporária de poder aquisitivo. A notícia trazia declaração de Firmino Paz de que "não cabe nenhum recurso contra a sua decisão de arquivar a petição de arguição de inconstitucionalidade da cobrança do empréstimo compulsório”, uma vez que o PGR é o titular da RP, cabendo a ele o exame da conveniência de encaminhar ou não as ações ao STF. A notícia comentava, também, a declaração do PGR de que era admissível aos contribuintes que se sentissem lesados diante do fato concreto o uso da via do mandado de segurança na justiça federal de primeira instância ${ }^{13}$.

\footnotetext{
${ }^{12}$ A limitação da pesquisa a esses dois jornais se deve a questões operacionais: facilidade no acesso às notícias digitalizadas e necessidade de restringir o volume de notícias, uma vez que a classificação foi feita de forma manual, pela leitura integral dos textos. Considera-se que essa escolha não retira a validade da análise, visto que o foco não está na realização de um levantamento exaustivo de casos, mas, sim, na identificação de uma amostra de casos de arquivamento de RPs que ganharam repercussão pública. Estratégia semelhante foi adotada em outros estudos que se valeram da cobertura midiática como um termômetro do tipo de inserção de instituições no cenário público em determinados contextos históricos - nesse sentido, ver Arguelhes, Oliveira e Ribeiro (2012) e Oliveira (2004, 2012).

${ }^{13}$ COMPULSÓRIO admite mandado de segurança. Folha de S. Paulo, São Paulo, p. 23, 24 jun. 1980. Disponível em: https:// acervo.folha.com.br/leitor.do? numero=7352\&keyword=\%22Procurador-Geral+da+Republica\%22\&anchor=4319976\&origem $=$ busca\&pd=498e658fd9288ccc2d9235835d06bd84. Acesso em: 5 fev. 2021.
} 
Nesse mesmo período, a Lei Orgânica da Magistratura Nacional (LOMAN) também atraiu diversos questionamentos de inconstitucionalidade, os quais Firmino Paz arquivou. Entre os mais noticiados estão o arquivamento de pedidos movidos por juízes do Rio de Janeiro, de Minas Gerais e de São Paulo. O arquivamento foi noticiado com a justificativa dada por Firmino Ferreira Paz de "não ter constatado a inconstitucionalidade alegada" ${ }^{14}$. Sobre o caso, a Folha de S. Paulo publicou declaração do ministro aposentado do STF Pedro Chaves, de que, embora o PGR tenha poder para arquivar a solicitação de representação de inconstitucionalidade, "quando arquiva um processo de representação a ele solicitado para que seja submetido ao exame e julgamento do STF, ocorre a usurpação de competência da nossa Suprema Corte"15.

Outro caso de arquivamento de grande repercussão foram os pedidos dirigidos ao PGR contra a Lei de Segurança Nacional (LSN), que também provocou críticas no sentido de usurpação de competência.

O procurador-geral da República, Firmino Ferreira Paz, não encaminhará para julgamento do Supremo Tribunal Federal, nenhuma solicitação de representação para que sejam declarados inconstitucionais dispositivos da Lei de Segurança Nacional. "Não pode ser inconstitucional uma lei que está citada em várias partes do texto constitucional”. Com essa observação, Firmino antecipou ontem, a decisão de mandar arquivar, evitando o exame do STF - uma anunciada solicitação de arguição de inconstitucionalidade da LSN (...) Assim, quem manda no processo de arguição de inconstitucionalidade é o procurador-geral, cujo poder vem recebendo críticas porque "usurpa a competência do STF”. Essa crítica é feita pelos advogados e representantes de entidades interessadas em solicitar ao STF a declaração de inconstitucionalidade da LSN. (PROCURADOR...,1980, p. 5) ${ }^{16}$

Na gestão de Mártires Coelho, houve maior incidência de notícias sobre arquivamentos de petições de inconstitucionalidade. Na seara eleitoral, Mártires

\footnotetext{
${ }^{14}$ ARQUIVADAS três ações contra lei da Magistratura. Folha de S. Paulo, São Paulo, p. 8, 5 out. 1979. Disponível em: https://acervo.folha.com.br/leitor.do? numero $=7089 \&$ key word=procurador $\&$ anchor $=4266810 \&$ origem $=$ busca\&pd=b57b93ee6b4fffe60e756ee401e8740f._Acesso em: 23 abr. 2020. Cf. também PROCURADOR defende Lei de Segurança. Folha de S. Paulo, São Paulo, p. 5, 2 out. 1980. Disponível em: https://acervo.folha.com.br/leitor.do?numero=74 $52 \&$ keyword=\%22Procurador - Geral $+\mathrm{da}+$ Republica $\% 22 \&$ anchor $=4266514 \&$ origem $=$ busca $\& p d=4 \mathrm{a} 161108 \mathrm{f} 9 \mathrm{df} 22 \mathrm{a} 248605 \mathrm{aab}$ 9029579b. Acesso em: 5 fev. 2021.

${ }^{15}$ LOM é inconstitucional. Folha de S. Paulo, São Paulo, p. 7, 4 ago. 1979. Disponível em: https://acervo.folha.com.br/leitor. do numero $=7037 \&$ keyword $=$ Procurador\&anchor $=4259187 \&$ origem $=$ busca\&pd=63f3f9729052a8633a4310f71681231e. Acesso em: 5 fev. 2021.

${ }^{16}$ PROCURADOR defende Lei de Segurança. Folha de S. Paulo, São Paulo, p. 5, 2 out. 1980. Disponível em: https://acervo.folha. com.br/leitor.do? numero $=7452 \&$ keyword $=\% 22$ Procurador - Geral + da + Republica $\% 22 \&$ anchor $=4266514 \&$ origem $=$ busca $\&$ pd $=4$ a161108f9df22a248605aab9029579b. Acesso em: 5 fev. 2021.
} 
Coelho arquivou pedidos contra resoluções do TSE sobre fidelidade partidária (Resoluções n. 11.985 e 12.017), e o caso de maior repercussão, que rendeu ao PGR a alcunha de "guarda à porta do STF", foi o arquivamento de representação proposta pelos juristas Celso Bastos, Godofredo da Silva Teles, Paulo Benevides e Antonio Mariz arguindo a inconstitucionalidade do Colégio Eleitoral. O caso foi noticiado como "escandaloso" pela Folha de S. Paulo.

Essa Constituição que aí temos, na qual alguns preceitos democráticos se encontram em promiscuidade com outros de corte totalitário, permite ao chefe do poder Executivo colocar uma espécie de guarda de plantão à porta de outro poder, o Judiciário, a fim de barrar a entrada de qualquer portador de reclamações contrárias aos interesses do governo. (GUARDA..., 1984, p. 2) ${ }^{17}$

Logo no início da sua gestão, repercutiu o arquivamento de representação proposta pelo deputado Odacir Klein (PMDB), questionando a constitucionalidade do Decreto-lei 1.910/1981, que aumentava as alíquotas das contribuições dos segurados e das empresas, destinadas ao custeio da Previdência Social. O PGR justificou o arquivamento afirmado que a norma não conflitava com a Constituição. Em notícia publicada no jornal $O$ Estado de S. Paulo, há transcrição de trechos da decisão de arquivamento do PGR,

Inocêncio Mártires Coelho salientou que "apesar de não exercer no particular tarefa sequer semelhante à função de juiz, o procurador-geral da República deve obedecer, na espécie, aquelas regras de bom-aviso ou princípios sábios que os juízes e tribunais costumam observar sempre que se defrontam com grave problema de ter que decidir sobre a validade das leis diante do texto da Constituição". Entre as regras aplicáveis ao "pacote" da Previdência Social, ele lembrou as seguintes: "Presumem-se constitucionais os atos legislativos; somente quando a colisão entre a lei e a Constituição se apresentar clara, aberta, manifesta ou inequívoca, é que os tribunais a devem reconhecer e proclamar; na dúvida, decidir-se-á, sempre, pela constitucionalidade; sempre que possível, adotar-se-á a exegese que torne a lei compatível com a Constituição, e a tradicional aplicação de uma norma, sem que se ponha em dúvida a sua constitucionalidade, é elemento importante no reconhecimento de que ela não conflita com a Constituição”. (PROCURADOR..., 1982, p. 14) ${ }^{18}$.

\footnotetext{
${ }^{17}$ GUARDA à porta do STF. Folha de S. Paulo. São Paulo, p. 2, 4 jun. 1984. Disponível em: https://acervo.folha.com.br/leitor.do? numero $=8793 \&$ keyword=\%22Procurador - Geral + da + Republica $\% 22 \&$ anchor $=4186428 \&$ origem $=$ busca $\&$ pd $=4 \mathrm{c} 839878 \mathrm{~b} 1 \mathrm{ad} 8 \mathrm{cf} 6$ 74022 fc99125dcdc. Acesso em: 5 fev. 2021.

${ }^{18}$ PROCURADOR rejeita alegação de inconstitucionalidade do 'pacote'. O Estado de S. Paulo. São Paulo, p. 14, 17 fev. 1982. Disponível em: https://acervo.estadao.com.br/pagina/\#!/19820217-32803-nac-0014-999-14-not/busca/procurador+geral+Rep\%C3\%BAblica. Acesso em: $1^{\circ}$ fev. 2021.
} 
Outro caso muito noticiado na gestão Mártires Coelho foi o veto ao pedido feito pelo governador do estado de São Paulo, Franco Montoro, arguindo a inconstitucionalidade da Lei Complementar 318/1983, que regulamentava a carreira dos funcionários públicos estaduais, determinando a incorporação das gratificações referentes ao exercício de cargo em confiança, aos vencimentos dos servidores. $\mathrm{O}$ governador alegava que a "Lei do Marinzão", como a norma ficou conhecida, havia sido aprovada por decurso de prazo, mas, por se tratar de lei complementar, requeria aprovação da maioria da Assembleia Legislativa para entrar em vigor. Mártires Coelho fundamentou o arquivamento do pedido, argumentando não ver irregularidade na tramitação da lei. O caso seguiu nos jornais por semanas, uma vez que houve recurso da procuradoria-geral do Estado ao STF, via reclamação, alegando "preservar a sua competência como guardião máximo da Constituição"19.

Foram noticiados, ainda, arquivamentos de pedidos de arguição de inconstitucionalidade de políticas nas áreas tributária e econômica. Exemplo disso é o pedido de arguição de inconstitucionalidade encaminhado ao PGR pelo Conselho Federal da $\mathrm{OAB}$ contra ato de negociação de crédito externo, firmado entre o Banco Central e um consórcio de bancos liderado pelo Citibank. A OAB alegava que o acordo era nocivo aos interesses econômicos e sociais do país. No entanto, Mártires Coelho justificou o arquivamento do pedido com base no parecer emitido pelo procurador-geral da Fazenda Nacional, sustentando que o pedido era inadmissível porque "contrato não é ato normativo" 20.

Na gestão de Sepúlveda Pertence, as notícias sobre arquivamento praticamente desaparecem. Foram dois os casos noticiados nos jornais pesquisados. Um deles foi o pedido encaminhado ao PGR pelo prefeito paulistano Jânio Quadros, questionando a constitucionalidade de decreto do Plano Bresser, que havia congelado as tarifas de ônibus por noventa dias ${ }^{21}$. O segundo caso trata de petição do Instituto dos Advogados de São Paulo arguindo a inconstitucionalidade da Lei 7.315/1985, que criou o Banco Meridional, com a desapropriação de ações do grupo Sulbrasileiro. Notícia do jornal O Estado de S. Paulo criticou essa ação do PGR, afirmando que,

\footnotetext{
${ }^{19}$ O PROCURADOR rejeita a ação contra Marinzão. O Estado de S. Paulo. São Paulo, p. 8, 23 abr. 1983. Disponível em: https:// acervo.estadao.com.br/pagina/\#!/19830426-33169-nac-0008-999-8-not/tela/fullscreen. Acesso em: 1º fev. 2021.

${ }^{20}$ NEGOCIAÇÃO é constitucional, diz procurador. O Estado de S. Paulo. São Paulo, p. 19, 20 jan. 1984. Disponível em: https:// acervo.estadao.com.br/pagina/\#!/19840120-33399-nac-0019-999-19-not/busca/procurador+geral+Rep\%C3\%BAblica. Acesso em: $1^{\circ}$ fev. 2021.

${ }^{21}$ JÂNIO arquivado. Folha de S. Paulo. São Paulo, p. A4, 31 ago. 1987. Disponível em: https://acervo.folha.com.br/leitor. do? numero=9976\&keyword=procurador\&anchor $=4298259$ \&origem $=$ busca\&originURL=\&pd=7b36fe129153d8cc4040fc4a364elb75. Acesso em: 14 fev. 2021.
} 
Ao arquivar a representação do Instituto dos Advogados, a Procuradoria Geral da República valeu-se do entulho autoritário que deu ao Executivo o poder de impedir que o Supremo Tribunal Federal decida sobre a constitucionalidade das leis. Mais ainda, a Procuradoria Geral, para determinar o arquivamento, valeu-se de argumentos antijurídicos (os fatos valem mais do que o Direito) e consagrou a intervenção estatal no domínio econômico como norma de fato e de direito. (OS FATOS..., 1985, p. 3$)^{22}$

Embora notícias sobre arquivamento de RPs tenham sido residuais na cobertura da atuação de Sepúlveda Pertence na esfera de controle de constitucionalidade, as notícias sobre o envio de ações ao STF, acompanhadas de parecer contrário ao pedido apresentado, em defesa da constitucionalidade da norma, foram comuns. Exemplo disso está em caso bastante noticiado à época, da RP questionando a Lei 7.232/1984 (Lei de Informática) e o Decreto-Lei 2.203/1984. O pedido de representação de inconstitucionalidade foi encaminhado ao PGR pelo senador Roberto Campos (PDSMT) e assinado por outros 53 parlamentares de diversos partidos, contestando o aspecto de reserva de mercado para o setor de informática.

Sepúlveda Pertence protocolou a RP e, posteriormente, encaminhou ao ministro Aldir Passarinho, relator da ação, documento em que defendia a constitucionalidade das normas. Sepúlveda Pertence justifica a submissão da RP ao Supremo em virtude da representatividade dos congressistas que subscreveram o pedido e da relevância social do tema ${ }^{23}$. Antes do julgamento pelo STF, o jornal O Estado de S. Paulo publicou declaração de Sepúlveda Pertence sobre o caso.

Compreendi que a eficácia da Lei de Informática e a própria segurança da sua defesa em que o governo está empenhado dependem de que cessem quaisquer dúvidas sobre sua constitucionalidade”, acrescentou o procurador-geral. Ele argumentou que "embora não fechando o caminho para o Supremo Tribunal e ao pedido de senadores e deputados, seja pela representatividade dos que subscrevem tal pedido, seja pela relevância do tema, a Procuradoria-Geral defendeu com plena convicção a constitucionalidade da lei. (SUPREMO..., 1986) ${ }^{24}$

\footnotetext{
${ }^{22}$ OS FATOS e a Constituição. O Estado de S. Paulo. São Paulo, p. 3, 22 out. 1985. Disponível em: https://acervo.estadao.com.br/ pagina/\#!/19851022-33940-nac-0003-999-3-not/tela/fullscreen. Acesso em: 14 fev. 2021.

${ }^{23}$ PROCURADOR contesta Campos. O Estado de S. Paulo. São Paulo, p. 19, 17 jan. 1987. Disponível em: https://acervo.estadao. com.br/pagina/\#!/19870117-34321-nac-0019-999-19-not/busca/procurador+geral+Rep\%C3\%BAblica. Acesso em: 14 fev. 2021.

${ }^{24}$ SUPREMO eliminará dúvidas. O Estado de S. Paulo. São Paulo, p. 26, 6 ago. 1986. Disponível em: https://acervo.estadao.com. br/pagina/\#!/19860806-34182-nac-0026-999-26-not. Acesso em: 4 fev. 2021.
} 
O Supremo não conheceu do pedido, assim como não conhecia de outras RPs em que Pertence se valeu do mesmo expediente. Na decisão desse caso específico, é mencionado que, embora até 1978 fosse facultado ao PGR encaminhar a representação com parecer contrário, conforme previsto no próprio regimento interno do Tribunal (art. 174, $\$ 1^{\circ}$ : "provocado por autoridade ou por terceiro para exercitar a iniciativa prevista neste artigo, o Procurador-Geral, entendendo improcedente a fundamentação da súplica, poderá encaminhá-la com parecer contrário”), a Emenda Regimental 7, aprovada em 23 de agosto de 1978, excluiu essa possibilidade.

Em seu voto, o ministro relator retomou as discussões sobre o papel do PGR na arguição de inconstitucionalidade, partindo da decisão do STF na Reclamação 849, que questionou a prerrogativa do PGR em protocolar ou não um pedido de RP no Supremo, e pontuando diversos pareceres e manifestações anteriores e posteriores a essa decisão, concluiu afirmando não ser admissível "que o Procurador Geral da República, declarando expressamente, logo na inicial, que a lei é constitucional, possa levar ao exame do Supremo Tribunal Federal representação contra a inconstitucionalidade dessa mesma lei." ${ }^{25}$

Seguiram o voto do relator, ministro Aldir Passarinho, os ministros Rafael Mayer; Djaci Falcão; Néri da Silveira; Oscar Corrêa; Sydney Sanches; Octavio Gallotti e Carlos Madeira. O ministro Célio Borja votou pelo conhecimento da ação, argumentando que:

O que esta Corte tem reconhecido como poder exclusivo do ProcuradorGeral da República é o de arguir a inconstitucionalidade indicando na lei questionada os pontos que submete a julgamento. Ao fazê-lo, o chefe do parquet federal age politicamente, isto é, com vistas à tutela de um interesse público que tem como relevante. Quantas vezes, na prática quotidiana deste Tribunal, o juízo jurídico posteriormente emitido pelo Procurador-Geral não infirma a inconstitucionalidade que inicialmente arguiu? Se se exigisse a afirmar a inicial da inconstitucionalidade como juízo jurídico do ProcuradorGeral, sua posterior contradita haveria de reputar-se retratação, e assim, findaria o processo por falta de objeto. ${ }^{26}$

De maneira geral, a cobertura jornalística da atuação do PGR no controle de constitucionalidade das leis permitiu identificar marcas visíveis de cada profissional que ocupou o posto no período. A marca mais visível da atuação de Firmino Ferreira Paz foi barrar a arguição de inconstitucionalidade da Lei de Segurança Nacional (LSN), muito utilizada pelo próprio PGR no oferecimento de representações e denúncias contra parlamentares (OLIVEIRA; RIBEIRO, 2021). Mártires Coelho deixou a marca de "guarda

\footnotetext{
${ }^{25}$ STF, RP 1.349/DF, Tribunal Pleno, Rel. Min. Aldir Passarinho, j. 8 set. 1988, p. 29.

${ }^{26}$ STF, RP 1.349/DF, Tribunal Pleno, Rel. Min. Aldir Passarinho, j. 8 set. 1988, p. 34-35.
} 
à porta do STF", arquivando pedidos de inconstitucionalidade de medidas caras ao Executivo federal, em especial no âmbito eleitoral. Sepúlveda Pertence deixou como principal marca a mudança de estratégia para barrar a judicialização da política, trocando o arquivamento pela emissão de parecer em defesa da constitucionalidade da norma contestada.

\section{Conclusão}

O artigo buscou descrever os padrões de judicialização da política observados no período de transição democrática no Brasil, a partir de duas perguntas descritivas: quais interesses foram atendidos pelo PGR; e qual a taxa de sucesso das demandas apresentadas em RPs.

O PGR foi bastante receptivo às demandas de servidores públicos e governadores, judicializando, principalmente, políticas estaduais ligadas ao federalismo e à administração pública. As normas que tratavam de criação ou desmembramento de municípios, de vantagens e benefícios de carreiras públicas e da organização das instituições da justiça e do Estado representaram 73\% do total de demandas, com pequenas variações entre os três procuradores. Na gestão de Firmino Ferreira Paz, tiveram maior destaque os temas das carreiras públicas e da organização das instituições da justiça; na de Mártires Coelho as políticas sobre a organização das instituições do Estado foram as mais questionadas; e na de Sepúlveda Pertence, a criação de municípios teve maior destaque.

Políticas federais foram judicializadas com menor frequência, representando 8\% do total de RPs protocoladas por Firmino Ferreira Paz, 3\% das ações propostas por Mártires Coelho, e 11\% dos pedidos enviados ao Supremo por Sepúlveda Pertence. Firmino Paz judicializou políticas federais atendendo, sobretudo, a interesses de associações profissionais; já Mártires Coelho atendeu a associações de magistrados; e Sepúlveda Pertence, à OAB.

O STF foi bastante receptivo à judicialização da política nesse período, decidindo favoravelmente ao pleito em $56 \%$ das ações. As chances de inviabilizar uma norma por RP no período eram pouco menores do que três em cinco, sendo de três em cinco no caso de normas estaduais, e pouco maiores do que um em cinco para diplomas federais. Como parâmetro de comparação, Taylor (2008) estimou que as chances de inviabilizar uma norma por meio de revisão judicial por meio de ação direta de inconstitucionalidade eram pouco maiores que um em cinco.

Os grupos de interesse mais atendidos pelo STF foram os magistrados e o Executivo federal. Os magistrados tiveram $75 \%$ de suas demandas atendidas ( $86 \%$ de 
sucesso nas demandas contra normas estaduais e $80 \%$ nas demandas contra normas federais); o Executivo federal também teve sucesso em 75\% de suas demandas (71\% nos diplomas estaduais e 100\% no questionamento de normas federais). Os governadores alcançaram uma taxa de sucesso geral elevada: $73 \%$ dos pedidos foram atendidos (74\% no questionamento de normas estaduais e 50\% quando questionaram normas federais).

O STF respondeu de forma mais favorável à burocracia jurídica do que às demais carreiras de Estado: a primeira obteve 60\% de respostas favoráveis; e as demais carreiras, $41 \%$. O grupo de trabalhadores e profissionais não vinculados ao Estado estiveram entre os menos atendidos pelo STF, com uma taxa de sucesso de $24 \%$ em suas demandas.

Embora as chances de inviabilizar judicialmente uma política fossem altas no período de transição democrática, elas não eram distribuídas igualmente entre os diferentes grupos de interesse que conseguiam passar pelo gatekeeper do Tribunal. Uma amostra da cobertura midiática da atuação do PGR em controle de constitucionalidade evidenciou que, no governo Figueiredo, foi comum a prática de barrar a judicialização de políticas, arquivando solicitações de representação de inconstitucionalidade. Na gestão de Firmino Paz, os arquivamentos que ganharam maior repercussão foram os dos pedidos arguindo a inconstitucionalidade da LOMAN e da LSN. Mártires Coelho, o "guarda à porta do STF", arquivou diversos pedidos de inconstitucionalidade de medidas caras ao Executivo federal no âmbito eleitoral, como a eleição presidencial por meio de colégio eleitoral.

No governo Sarney, com Sepúlveda Pertence como Procurador-Geral da República, verificou-se uma intensificação do uso do controle de constitucionalidade, sendo residuais notícias do arquivamento de pedidos de RP. Em contrapartida, foram mais comuns relatos do envio de ação ao Supremo, acompanhadas de parecer contrário à inconstitucionalidade das normas questionadas.

Pode-se esboçar dois padrões de judicialização da política no período: no governo Figueiredo, os PGRs privilegiaram a judicialização da política como estratégia de governo (em especial, dos Executivos) e em defesa de grupos de interesses econômicos centrados nas políticas dos estados. Já no governo Sarney, o PGR privilegiou a judicialização como estratégia da burocracia estatal, dando, também, um pouco mais de espaço a interesses de setores mais amplos da sociedade e contestando, com maior frequência, políticas federais, em comparação ao governo anterior. Em termos de resultados, as demandas apresentadas pelos PGRs no governo Figueiredo alcançaram maior taxa de sucesso no STF: 70\% de resposta favorável, em comparação a $49 \%$ no governo Sarney. 


\section{Referências}

ARANTES, Rogério B. Ministério Público e política no Brasil. São Paulo: Editora Sumaré, 2002.

ARGUELHES, Diego Werneck; SÜSSEKIND, Evandro P. Judicialização antes da democratização?: o Supremo Tribunal Federal e o destino da Emenda Constitucional das 'Diretas Já. Pensar Revista de Ciências Jurídicas, v. 23, n. 4, 2018, p. 1-16.

ARGUELHES, Diego Werneck; OLIVEIRA, Fabiana Luci de; RIBEIRO, Leandro Molhano. Ativismo judicial e seus usos na mídia brasileira. Revista Direito, Estado e Sociedade, n. 40, p. 34-64, 2012.

ARQUIVADAS três ações contra lei da Magistratura. Folha de S. Paulo, São Paulo, p. 8, 5 out. 1979. Disponível em: https://acervo.folha.com.br/leitor. do? numero $=7089 \&$ keyword $=$ procurador $\&$ anchor $=4266810 \&$ origem $=$ busca $\& p d=$ b57b93ee6b4fffe60e756ee401e8740f. Acesso em: 23 abr. 2020.

AVRITZER, Leonardo; MARONA, Marjorie Corrêa. Judicialização da política no Brasil: ver além do constitucionalismo liberal para ver melhor. Revista Brasileira de Ciência Política, v. 15, p. 69-94, 2014.

BARROSO, Luís Roberto. O Supremo Tribunal Federal em 2016: o ano que custou a acabar. Consultor Jurídico: ConJur, São Paulo, jan 2017. Disponível em: https://s.conjur.com.br/dl/ retrospectiva-2016-barroso-parte.pdf. Acesso em: 2 fev. 2021.

BRASIL. Ministério Público Federal. Memorial MPF. Galeria de membros. Brasília, [2021]. Disponível em: https://memorial.mpf.mp.br/nacional. Acesso em: 15 abr. 2021.

CÂMARA, Heloísa Fernandes. STF na ditadura militar brasileira: um tribunal adaptável? Tese (Doutorado em Direito). Universidade Federal do Paraná, Curitiba, 2017.

CANÁRIO, Pedro; GALLI, Marcelo. Os excessos deste momento devem servir para rever o papel do MP e da Justiça. Consultor Jurídico: ConJur. São Paulo, 13 jul. 2016.

CARVALHO, Ernani Rodrigues. Em busca da judicialização da política no Brasil: apontamentos para uma nova abordagem. Revista de Sociologia e Política, n. 23, p. 127-139, 2004.

COMPULSÓRIO admite mandado de segurança. Folha de S. Paulo, São Paulo, p. 23, 24 jun. 1980. Disponível em: https://acervo.folha.com.br/leitor.do?numero $=7352 \& k e y w o r d=\% 22 \operatorname{Pr}$ ocurador-Geral+da+Republica\%22\&anchor $=4319976 \&$ origem $=$ busca $\&$ pd $=498$ e658fd9288c cc2d9235835d06bd84. Acesso em: 5 fev. 2021.

DOMINGO, Pilar. Judicialization of politics or politicization of the judiciary: recent trends in Latin America. Democratization, v. 11, n. 1, p. 104-126, 2004.

OS FATOS e a Constituição. O Estado de S. Paulo. São Paulo, p. 3, 22 out. 1985. Disponível em: https://acervo.estadao.com.br/pagina/\#!/19851022-33940-nac-0003-999-3-not/tela/ fullscreen. Acesso em: 14 fev. 2021. 
FUNDAÇÃO GETÚlio VARGAS. Centro de Pesquisa e Documentação de História Contemporânea do Brasil. Dicionário histórico-biográfico brasileiro. Rio de Janeiro, [2021]. Disponível em: https://cpdoc.fgv.br/acervo/dhbb. Acesso em: 15 abr. 2021.

GUARDA à porta do STF. Folha de S. Paulo. São Paulo, p. 2, 4 jun. 1984. Disponível em: https://acervo.folha.com.br/leitor.do? numero=8793\&keyword=\%22Procurador-Geral $+\mathrm{da}+\mathrm{R}$ epublica\%22\&anchor $=4186428 \&$ origem $=$ busca\&pd $=4 \mathrm{c} 839878 \mathrm{~b} 1 \mathrm{ad} 8 \mathrm{cf} 674022 \mathrm{fc} 99125 \mathrm{dcdc}$.

Acesso em: 5 fev. 2021.

INSTITUTO BRASILEIRO DE GEOGRAFIA E ESTATISTICA. Atlas nacional do Brasil Milton Santos. Rio de Janeiro, IBGE, 2010.

JÂNIO arquivado. Folha de S. Paulo. São Paulo, p. A4, 31 ago. 1987. Disponível em: https://acervo.folha.com.br/leitor.do?numero=9976\&keyword=procurador\&anchor $=$ 4298259\&origem $=$ busca\&originURL $=\& \mathrm{pd}=7 \mathrm{~b} 36 \mathrm{fe} 129153 \mathrm{~d} 8 \mathrm{cc} 4040 \mathrm{fc} 4 \mathrm{a} 364 \mathrm{e} 1 \mathrm{~b} 75 . \quad$ Acesso em: 14 fev. 2021.

KAPISZEWSKI, Diana. How courts work: institutions, culture, and the Brazilian Supremo Tribunal Federal. In: COUSO, Javier; HUNEEUS; Alexandra; SIEDER, Rachel. Cultures of legality: judicialization and political activism in Latin América. Cambridge: Cambridge University Press, 2010, p. 51-77.

KOERNER, Andrei. Sobre a evolução do controle da constitucionalidade no Brasil: uma análise crítica. In: FONSECA, Ricardo Marcelo (org). As formas do direito: ordem razão, decisão: experiências jurídicas antes e depois da modernidade. Curitiba: Juruá, 2012, p. 527-568.

LOM é inconstitucional. Folha de S. Paulo, São Paulo, p. 7, 4 ago. 1979. Disponível em: http:// acervo.folha.com.br/leitor.do? numero $=7037 \&$ keyword $=$ Procurador $\&$ anchor $=4259187 \&$ ori gem=busca\&pd=63f3f9729052a8633a4310f71681231e. Acesso em: 5 fev. 2021.

MACIEL, Débora A.; KOERNER, Andrei. O processo de reconstrução do Ministério Público na transição política (1974-1985). Revista Debate, Porto Alegre, v. 8, n. 3, p. 97-117, 2014.

MACIEL, Débora A.; KOERNER, Andrei. Sentidos da judicialização da política: duas análises. Lua Nova: revista de cultura e política, n. 57, p. 113-133, 2002. Disponível em: https://www. cedec.org.br/questoes-de-direito---ano-2002---no-57. Acesso em: 6 jun.2021.

MENDES, Gilmar Ferreira. O controle de constitucionalidade: aspectos jurídicos e políticos. São Paulo, Saraiva, 1990.

MENDES, Gilmar Ferreira. Considerações sobre o papel do Procurador-Geral da República no controle abstrato de normas sob a Constituição de 1967/69: proposta de releitura. Revista de Informação Legislativa, n. 135, p. 141-152, jul./set. 1997.

NEGOCIAÇÃO é constitucional, diz procurador. O Estado de S. Paulo. São Paulo, p. 19, 20 jan. 1984. Disponível em: https://acervo.estadao.com.br/pagina/\#!/19840120-33399-nac0019-999-19-not/busca/procurador+geral+Rep\%C3\%BAblica. Acesso em: 1º fev. 2021. 
OLIVEIRA, Fabiana Luci de. O Supremo Tribunal Federal no processo de transição democrática: uma análise de conteúdo dos jornais Folha de S. Paulo e O Estado de S. Paulo. Revista de Sociologia e Política, vol. 22, p. 101-118, 2004.

OLIVEIRA, Fabiana Luci de. STF: do autoritarismo à democracia. Rio de Janeiro: Elsevier, 2012.

OLIVEIRA, Fabiana Luci de. Agenda suprema: interesses em disputa no controle de constitucionalidade das leis no Brasil. Tempo Social, v. 28, n. 1, p. 105-133, 2016.

OLIVEIRA, Fabiana Luci de. Agenda decisória do Supremo Tribunal no período de transição democrática: judicialização da política? Revista Plural, São Paulo, v. 26, p. 7495, 2 ago./set., 2019.

OLIVEIRA, Fabiana Luci de; FALAVINHA, Diego H. S.; BRAGHIN, Simone. Processo decisório no STF e o caso da reforma do Judiciário. Revista Direito e Práxis, v. 6, p. 365-394, 2015.

OLIVEIRA, Fabiana Luci de; RIBEIRO, Desirée Ferreira Marques. Atuação política do Procurador-Geral da República na transição democrática no Brasil. Revista Direito e Práxis, Ahead of print, 2021.

PROCURADOR contesta Campos. O Estado de S. Paulo. São Paulo, p. 19, 17 jan. 1987. Disponível em: https://acervo.estadao.com.br/pagina/\#!/19870117-34321-nac-0019-999-19not/busca/procurador+geral+Rep\%C3\%BAblica. Acesso em: 14 fev. 2021.

PROCURADOR defende Lei de Segurança. Folha de S. Paulo, São Paulo, p. 5, 2 out. 1980. Disponível em: https://acervo.folha.com.br/leitor.do?numero=7452\&keyword=\%22Procurad or-Geral+da+Republica\%22\&anchor $=4266514$ \&origem $=$ busca\&pd=4a161108f9df22a248605a ab9029579b. Acesso em: 5 fev. 2021.

O PROCURADOR rejeita a ação contra Marinzão. O Estado de S. Paulo. São Paulo, p. 8, 23 abr. 1983. Disponível em: https://acervo.estadao.com.br/pagina/\#!/19830426-33169-nac-0008999-8-not/tela/fullscreen. Acesso em: $1^{\circ}$ fev. 2021.

PROCURADOR rejeita alegação de inconstitucionalidade do 'pacote'. O Estado de S. Paulo. São Paulo, p. 14, 17 fev. 1982. Disponível em: https://acervo.estadao.com.br/ pagina/\#!/19820217-32803-nac-0014-999-14-not/busca/procurador+geral+Rep\%C3\%BAblica. Acesso em: $1^{\circ}$ fev. 2021.

RIBEIRO, Leandro Molhano; ARGUELHES, Diego Werneck. Contextos da judicialização da política: elementos para um novo mapa teórico. Revista Direito GV, v. 15, n. 2, p.1-21, 2019.

SUPREMO eliminará dúvidas. O Estado de S. Paulo. São Paulo, p. 26, 6 ago. 1986. Disponível em: https://acervo.estadao.com.br/pagina/\#!/19860806-34182-nac-0026-99926-not. Acesso em: 4 fev. 2021. 
TATE, C. Neal, VALLINDER, Torbjörn (ed.). The global expansion of judicial power. New York: New York University Press, 1995.

TAYLOR, Matthew. Judging policy: courts and policy reform in democratic Brazil. Stanford: University Press, 2008.

TAYLOR, Matthew M.; DA ROS, Luciano. Os partidos dentro e fora do poder: a judicialização como resultado contingente da estratégia política. Dados, Rio de Janeiro, v. 51, n. 4 , p. $825-864,2008$.

VIANNA, Luiz Werneck; BURGOS, Marcelo Baumann; SALLES, Paula Martins. Dezessete anos de judicialização da política. Tempo Social, v. 19, n. 2, p. 39-85, 2007.

VIEIRA, Oscar Vilhena. Supremo Tribunal Federal: jurisprudência política. São Paulo: Revista dos Tribunais, 1994.

\section{Jurisprudência citada}

BRASIL. Supremo Tribunal Federal (Tribunal Pleno). Representação 1349/DF. Relator: Min. Aldir Passarinho, 8 de setembro de 1988. Disponível em: https://stf.jus.br/portal/inteiroTeor/ obterInteiroTeor.asp? numero=1349\&classe=Rp. Acesso em: 3 jun. 2021.

\section{Legislação citada}

BRASIL. [Constituição (1946)]. Constituição dos Estados Unidos do Brasil (de 18 de setembro de 1946). Brasília: Presidência da República, [1985]. Disponível em: https://www. planalto.gov.br/ccivil_03/Constituicao/Constituicao46.htm. Acesso em: 15 abr. 2021.

BRASIL. Regimento Interno do Supremo Tribunal Federal, de 18 de junho de 1970. Brasília: STF, [1979]. Disponível em: https://portal.stf.jus.br/textos/verTexto. asp? servico=bibliotecaConsultaProdutoBibliotecaRI\&pagina=1970. Acesso em: 14 fev. 2021 . 